\title{
Physical and chemical characteristics of after-reclamation dust from used sand moulds
}

\author{
Rafal Dańko $^{1} \cdot$ Jan Jezierski ${ }^{2} \cdot$ Mariusz Holtzer $^{1}$
}

Received: 25 June 2015 / Accepted: 18 September 2015 /Published online: 24 February 2016

(C) The Author(s) 2016. This article is published with open access at Springerlink.com

\begin{abstract}
The paper presents the results of investigations of physical and chemical properties of after reclamation dust that is generated in the foundry industry. Universally applied mechanical reclamation processes of spent moulding sands generate large amounts of after-reclamation dusts containing mainly rubbed spent binding agents and quartz dusts. An amount of after-reclamation dusts - in dependence of the reclamation system efficiency and the reclaim dedusting system-can reach 5-10\% in relation to the total reclaimed spent moulding sand. After-reclamation dusts originated from spent moulding sands with different kinds of resins mostly belong to dangerous wastes, since they contain chemo-setting binders with dangerous substances removed in the reclamation process. None of the companies producing mechanical reclamation systems offers presently the complex technology and equipment for utilisation of after reclamation dusts, which would meet technical and economic expectations of foundry plants. The paper presents the results of research carried out at the Faculty of Foundry Engineering AGH UST in Cracow which aims on the determination of possibilities of using the post-reclamation dust generated during mechanical reclamation of used moulding sands with organic resins as a source of energy. Different dusts generated in the mechanical reclamation process of used organic sands, delivered from foundries,
\end{abstract}

This article is part of the Topical Collection on DUST

Rafał Dańko

rd@agh.edu.pl

1 AGH University of Science and Technology, Mickiewicza 30 Street, 30-059 Krakow, Poland

2 Silesian University of Technology, Towarowa 7 Street, 44-100 Gliwice, Poland were tested to determine their chemical composition, granular characterisation and physicochemical properties. As a result of the investigations, possible ways to utilise the dusts are presented.

Keywords Dust · Recycling · Environmental protection . Reclamation $\cdot$ Moulding and core sands

\section{Introduction}

It is estimated that approximately $103 \mathrm{mln}$ tonnes of castings are produced every year. Eighty per cent of this production is carried out in moulds produced from silica sand bonded with binding materials, mostly bentonite and organic resins (Holtzer et al. 2014). To produce $1 \mathrm{~kg}$ of casting, a sand mould of ca. $4 \mathrm{~kg}$ must be produced. Due to environmental procedure guidelines and to make the process more economically efficient, after the casting is produced, the mould is broken and the silica sand is recovered by means of thermal or mechanical reclamation treatments, and then, it is reused in casting production (Dańko et al. 2007; Łucarz et al. 2014; Łucarz 2015; Dańko 2010; Skrzyński et al. 2013). The process of reclamation of used sand generates large amounts of dusts, which most often contain binding material rubbed from the sand grain surface.

According to data found in practical foundry knowledge, no-bake moulding sands with organic resins applied in foundry practice currently have the highest share in casting production out of all technologies using no-bake sands in which the quartz matrix is bound by chemo-setting binding agents (Holtzer 2011).

Figure 1 presents an example of moulds produced with sand bonded with furfuryl resin after casting, a mould prepared for the crushing process and the casting that is produced. 

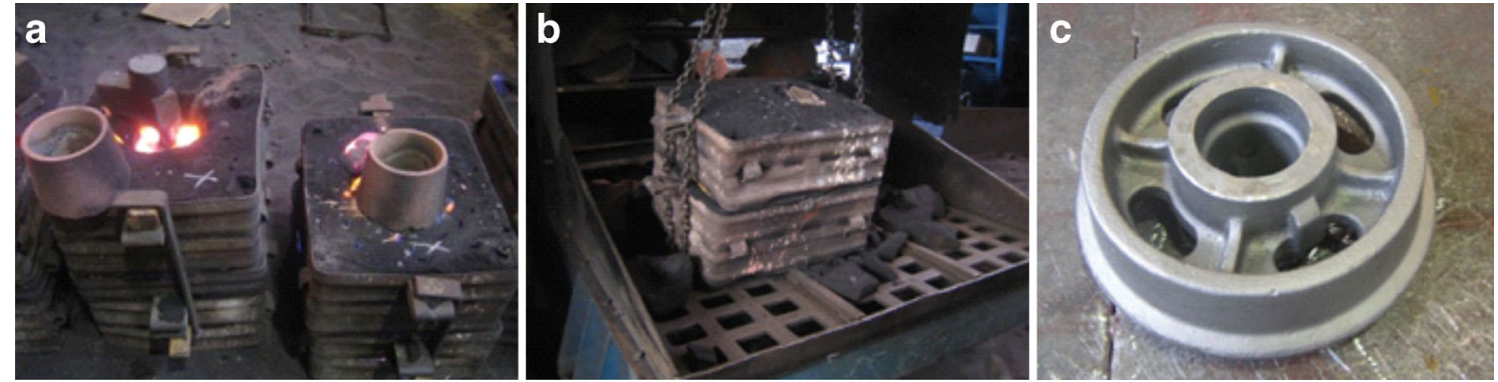

Fig. 1 The view of the moulds after casting (a), prepared for the crushing (b) and the casting (c)

Mechanical reclamation processes of spent moulding sands, which are the most often used method of utilising the sand matrix from moulds used for casting production, generate large amounts of after-reclamation dusts containing mainly rubbed spent binding agents and quartz dusts. Afterreclamation dusts originating from spent moulding sands with different kinds of resins mostly comprise dangerous wastes since they contain chemo-setting binders with dangerous substances that have been removed in the reclamation process.

Contrary to dusts generated in metallurgical processes, none of the companies producing mechanical reclamation systems presently offer complex technology and equipment to utilise after-reclamation dusts and other types of dusts that would meet the technical and economic expectations of foundry plants (Jezierski and Janerka 2011; Dańko et al. 2014; Laforest and Duchesne 2006; Stegemann et al. 2000; Vargas et al. 2006; Vieira and Monteiro 2009; Danko et al. 2014; Dondi et al. 1997a, b; Pribulova and Gengel 2010; Fontes et al. 2013; Holtzer et al. 2015).

Waste management of dusts along with treatment of hazardous air pollutants is essential for each foundry plant (Crandell 2006; Reardon et al. 1995). The possible sources of dust and hazardous air pollutant (HAP) emission in an iron alloys foundry is presented in Fig. 2.
Storage and thermal utilisation of dusts generated during mechanical reclamation is associated with high costs. Some foundry plants, having spacious backup facilities, store the dusts in big bags.

\section{Physicochemical properties of after-reclamation dusts}

The following basic physical and chemical properties of after-reclamation dusts were tested in order to develop a utilisation method for after-reclamation dusts generated in the dry reclamation process of moulding sands with furfuryl resins:

- Chemical composition and properties

- Grain size analysis, physical and bulk density of dusts from the reclamation of tested moulding sands

- Loss on ignition

- Energetic properties.

Based on these four different properties, dusts originating from the reclamation process of no-bake furan resins and two various dusts originating from the reclamation process of
Fig. 2 Sources of dust and hazardous air pollutant (HAP) emission in an iron alloy foundry (Crandell 2006)

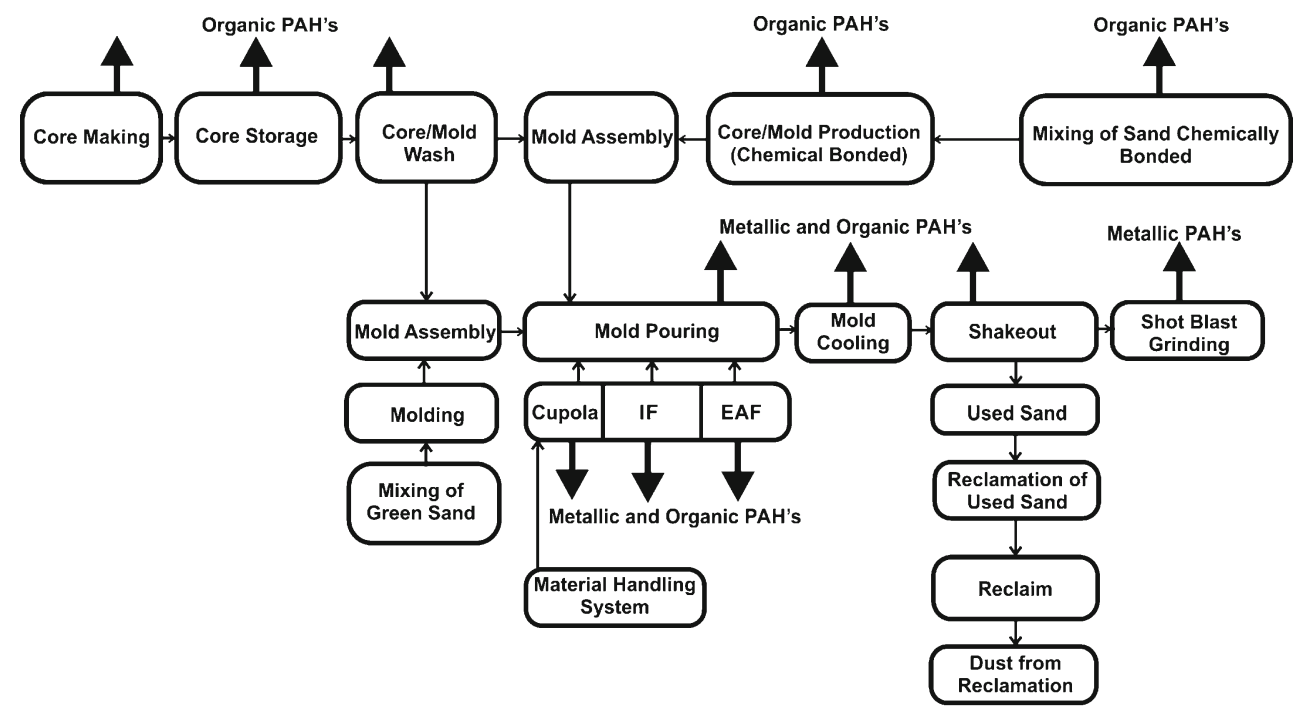



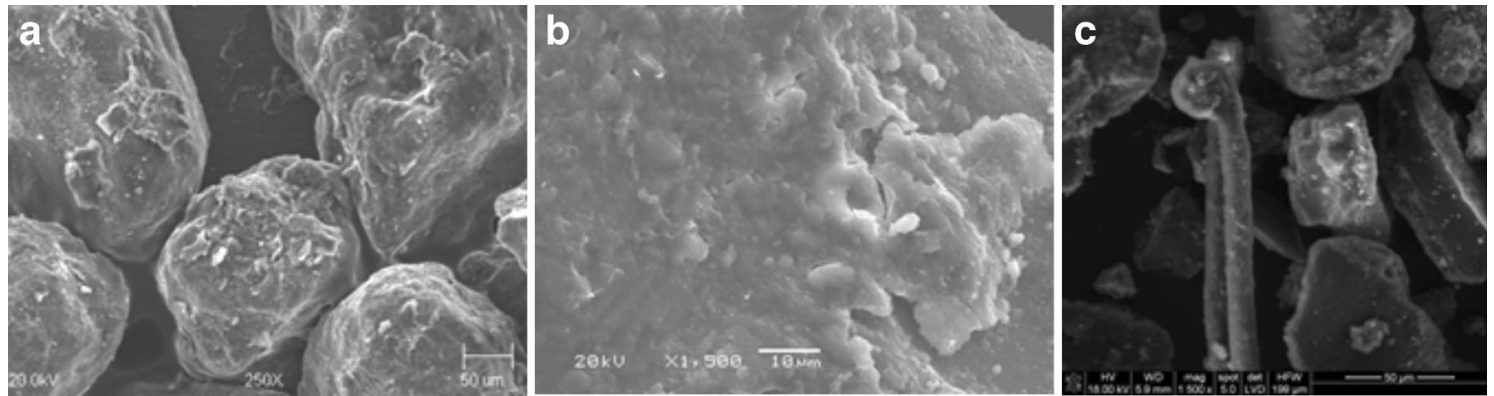

Fig. 3 SEM pictures of used sand after breaking the mould — case D1, magnification $\times 250$ (a), surface of the used sand, magnification $\times 1500$ (b), and dust rubbed from the used sand after the process of mechanical reclamation, magnification $\times 1500$ (c)

basic resin technology (ALPHASET, alkyd) were chosen for the tests. The experiments were conducted at the Faculty of Foundry Engineering, AGH University of Science and Technology within the INNOTECH Project entitled "Elaboration of innovative technology of after reclamation dusts thermal utilization - in an aspect of waste heat recovery", which is aimed at development of a utilisation method of afterreclamation dusts generated in the dry reclamation process of moulding sands. Dusts chosen for the investigations came from various Polish foundry plants. These dusts were marked as follows:

Dusts with acid resin residues applied in the investigations

D1: Dust coming from a foundry producing steel castings of a mass up to 20 tons. Composition of the furfuryl moulding sand on a quartz matrix: sand, 100 parts by mass; furfuryl resin, 1.3-1.6 parts by mass; and hardener, $0.7-0.9$ parts by mass. In this moulding sand, Kaltharz XA20 resin was used as a binder, while 100T3 was used as an activator (bulletins and manufacturers information). The sand used here was subjected to the mechanical reclamation process in a GUT reclaimer and to magnetic separation. The amount of after-reclamation dusts per year was $600-840$ tons.

D2: Dust coming from a foundry producing grey iron castings of a mass up to 80 tons produced in moulding sand with furfuryl resin: Furanol FR75A and hardener PU5S (bulletins and manufacturers information). The initial composition of the moulding sand was the following: sand, 100 parts by mass; furfuryl resin, 1.0 parts by mass; and hardener, 0.5 parts by mass. The powdery fraction originated from reclamation of the spent moulding sand in an IMF company reclaimer was submitted for utilisation by a special unit. The amount of afterreclamation dusts per year was ca. 1500 tons.

D4: Dust coming from a foundry producing grey and ductile iron castings of a mass up to 15 tons. Moulds were made with furfuryl moulding sand with the following initial composition: matrix: 90 mass\% reclaim of highsilica sand +10 mass $\%$ fresh high-silica sand, together 100 parts by mass; Kaltharz 8117 furan resin, 0.90 parts by mass; and 100T3 activator, 0.35 parts by mass (bulletins and manufacturers). The spent moulding sand reclamation process was conducted in a vibratory crusher and
Table 1 Basic physicochemical properties of the investigated after-reclamation dusts from moulding sands with furfuryl resins and with alkaline resins

\begin{tabular}{|c|c|c|c|c|c|c|}
\hline \multirow[t]{3}{*}{ Determined properties of the dust } & \multicolumn{6}{|c|}{ Marking of after-reclamation dust } \\
\hline & \multicolumn{4}{|c|}{ Dust from furfuryl sands } & \multicolumn{2}{|c|}{$\begin{array}{l}\text { Dust from } \\
\text { alkaline sands }\end{array}$} \\
\hline & D1 & D2 & D4 & D6 & D3 & D7 \\
\hline Mass density $\left(\mathrm{g} / \mathrm{cm}^{3}\right)$ (average value) & 2.08 & 2.40 & 1.40 & 1.62 & 2.50 & 1.85 \\
\hline $\mathrm{pH}$ value & 5.02 & 4.14 & 5.52 & 4.30 & 10.2 & 9.01 \\
\hline Moisture (\% by mass) & 1.60 & 0.80 & 3.10 & 2.50 & 1.30 & 1.15 \\
\hline Acid demand value (ADV) & - & - & - & - & 40.50 & 24.50 \\
\hline Electrolytic conductivity (mS) & 4.12 & 2.11 & 8.82 & 4.51 & 7.35 & 0.84 \\
\hline Loss on ignition at temp. $950{ }^{\circ} \mathrm{C}$ ( $\%$ by mass $)$ & 18.96 & 10.24 & 44.36 & 28.09 & 5.50 & 22.17 \\
\hline $\begin{array}{l}\text { Emissivity of gases at temperature } 1000{ }^{\circ} \mathrm{C} \text { in } \mathrm{CO}_{2} \\
\left(\mathrm{~cm}^{3} / \mathrm{g} \text { of dust }\right)\end{array}$ & 69 & 45 & 165 & 111 & 36 & 94 \\
\hline
\end{tabular}


Fig. 4 Mass density and emissivity of gases at $1000^{\circ} \mathrm{C}$ as a function of loss of ignition of the investigated dusts

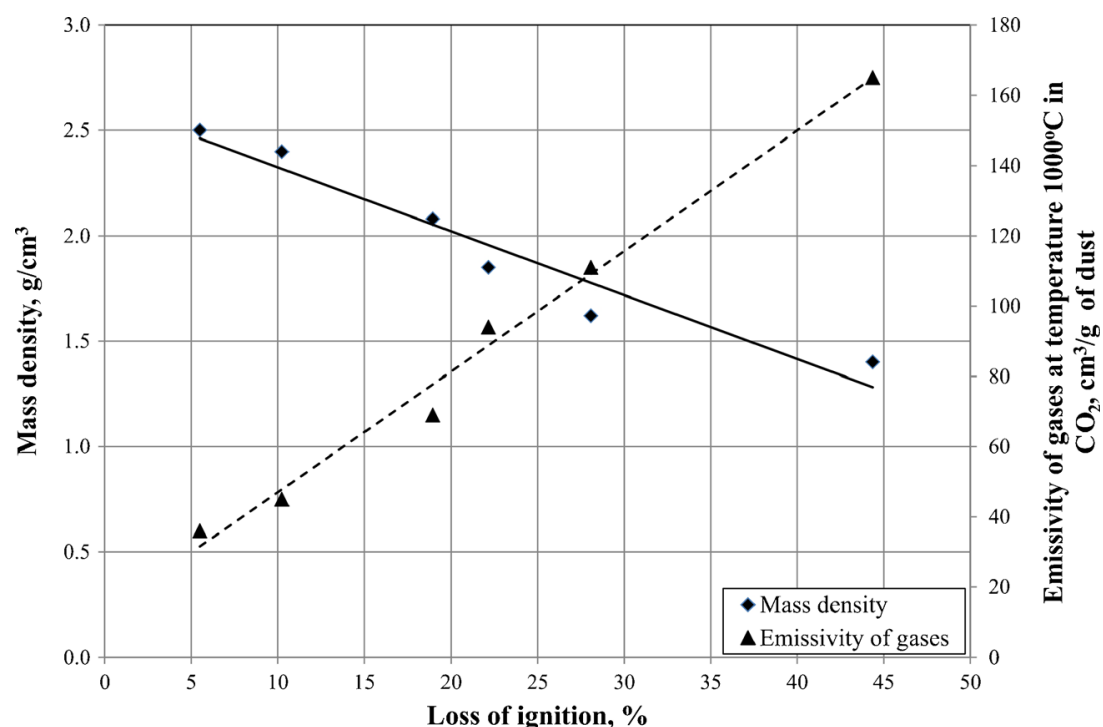

column reclaimer (IMF company) with a yield of 1520 tons/h. The after-reclamation powdery fraction in amounts of 900-1200 tons per year was submitted for utilisation by a special unit.

D6: Dust coming from a foundry producing ductile iron castings of a mass up to 55 tons. Moulds were produced in furfuryl moulding sand containing Furanol $75 \mathrm{~A}$ resin and PU6 hardener (bulletins and manufacturers information). The initial composition was the following: highsilica sand, 100 parts by mass; Furanol 75A resin, 0.8 parts by mass; and PU6 hardener, 0.40 parts by mass. The reclamation process was conducted by the mechanical method in devices of the GUT company. The afterreclamation dusts amounting per year to approximately 180 tons were handed over to an external company.
Dusts with basic resin residues applied in the investigations (phenolic, alkyd, ALPHASET type resins)

D3: Dust coming from a foundry producing steel castings of a mass up to 12 tons. Castings were produced in moulds prepared with ALPHASET moulding sand with an initial composition of matrix ( $40 \%$ of fresh high-silica sand and $60 \%$ of reclaim). As a binder in sand, phenolic binder Permabind 44 with ester hardener Permabind 132 was applied (bulletins and manufacturers information). The spent moulding sand reclamation process was conducted in a vibratory crusher and column reclaimer (of the IMF company) with a yield of 15-20 tons/h.

D7: Dust coming from a foundry producing steel castings of a mass up to 75 tons. Castings were produced in alkyd
Table 2 Chemical composition of the investigated afterreclamation dusts from the moulding sand with furfuryl resins and with alkaline resins

\begin{tabular}{lllllll}
\hline \multirow{2}{*}{ Chemical component } & \multicolumn{5}{l}{ Marking of after-reclamation dust, content in \% by mass } & \\
\cline { 2 - 7 } & $\mathrm{D} 1$ & $\mathrm{D} 2$ & $\mathrm{D} 4$ & $\mathrm{D} 6$ & $\mathrm{D} 3$ & $\mathrm{D} 7$ \\
\hline $\mathrm{Al}_{2} \mathrm{O}_{3}$ & 9.74 & 1.18 & $3.05-3.31$ & 7.65 & 13.12 & 10.03 \\
$\mathrm{C}$ & $14.3-18.96$ & $6.2-10.24$ & $34.8-3.16$ & $21.3-28.1$ & $3.1-5.3$ & $16.3-19.2$ \\
$\mathrm{CaO}$ & 0.82 & 0.15 & $0.76-0.81$ & 0.35 & 0.62 & 0.51 \\
$\mathrm{Cl}$ & 0.008 & 0.007 & 0.020 & 0.003 & 0.014 & 0.012 \\
$\mathrm{Fe}_{2} \mathrm{O}_{3}$ & 6.90 & 1.12 & $2.85-3.06$ & 3.64 & 1.99 & 3.51 \\
$\mathrm{~K}_{2} \mathrm{O}$ & 0.52 & 0.19 & 0.59 & 0.23 & 1.92 & 0.14 \\
$\mathrm{MgO}$ & 0.77 & 0.08 & $3.08-3.19$ & 0.16 & 1.70 & 0.92 \\
$\mathrm{Na}_{2} \mathrm{O}$ & 0.21 & 0.11 & 0.44 & 0.065 & 0.44 & 0.54 \\
$\mathrm{SiO}_{2}$ & 53.53 & 82.70 & av. 40.00 & 50.05 & 71.70 & 50.80 \\
$\mathrm{SO}_{3}$ & 2.75 & 1.13 & $4.9-5.0$ & 4.63 & 0.15 & 1.12 \\
$\mathrm{ZrO}_{2}$ & 1.08 & 0.078 & $0.045-.22$ & 2.02 & 0.23 & 2.06 \\
$\mathrm{Total}$ & $87.9-92.6$ & $93.0-97.05$ & $90.53-9.8$ & $90.1-96.90$ & 97.38 & 91.82 \\
\hline
\end{tabular}


Table 3 Selected data of the dust-size analysis of dusts from the reclamation of moulding sands with furfuryl resins and with alkaline resins

\begin{tabular}{llllllll}
\hline Determined size, parameter of dust & \multicolumn{7}{l}{ Marking of after-reclamation dust } \\
\cline { 2 - 7 } & D1 & D2 & D4 & D6 & D3 & D7 \\
\hline Arithmetic mean of dust particle diameter $(\mu \mathrm{m})$ & 54.23 & 49.12 & 31.26 & 44.11 & 68.22 & 46.79 \\
Specific surface of dust particles $\left(\mathrm{cm}^{2} / \mathrm{g}\right)$ & 9638 & 6927 & 18,998 & 11,503 & 6037 & 10,143 \\
Homogeneity of dust & 0.79 & 0.71 & 0.89 & 0.89 & 0.81 & 0.89 \\
$\begin{array}{l}\text { Mass fraction of dust particles sized 1.0-56.0 } \mu \mathrm{m} \\
\quad \text { (\% by mass) }\end{array}$ & 65.652 & 73.98 & 90.03 & 76.59 & 40.24 & 35.39 \\
\hline
\end{tabular}

moulding sand containing, as its matrix, high-silica sand and chromite sand (in a proportion of 5:7:1, respectively). As a binder in sand, the alkyd binder resin SL2002 and hardener KL were applied (bulletins and manufacturers information). The reclamation process was performed by the mechanical method in a GUT reclaimer. Afterreclamation dusts amounting, per year, to approximately 1500-1800 tons were handed over to an external company.

Figure 3 presents examples of SEM pictures of used sand after breaking the mould (case D1), the surface of the used sand and the dust rubbed from the used sand after the process of mechanical reclamation had been conducted.

\section{Results of investigations}

In order to assess the possibility of storage or management of after-reclamation dusts, it is necessary to determine their basic physicochemical properties.
The basic physicochemical properties of the investigated after-reclamation dusts are collected in Table 1 for moulding sands with furfuryl resins and with alkaline resins. Figure 4 presents the relationship between mass density and emissivity of gases at $1000{ }^{\circ} \mathrm{C}$ as a function of loss on ignition (LOI) of the investigated dusts. It can be noticed that the mass density of the dusts decreases with its loss on ignition. The emissivity of gasses measured in a temperature of $1000{ }^{\circ} \mathrm{C}$ increases with the growing value of the LOI of the investigated dusts.

The chemical composition of the investigated afterreclamation dusts from the moulding sands with furfuryl resins and with alkaline resins (data in round brackets) is given in Table 2.

The main component of after-reclamation dusts is silica. Its content equals from 40 to more than 80 mass $\%$. Moreover, the less $\mathrm{SiO}_{2}$ in the dusts, the more substances containing carbon (which means binding agents have been removed from the sand grains' surfaces). Thus, it can be assumed that the more carbon compounds there are in such dusts, the more efficient the reclamation process is and that the dedusting system is properly set (it does not carry off excessive amounts of the matrix).
Fig. 5 Arithmetic mean and specific surface of investigated dusts vs. their loss on ignition

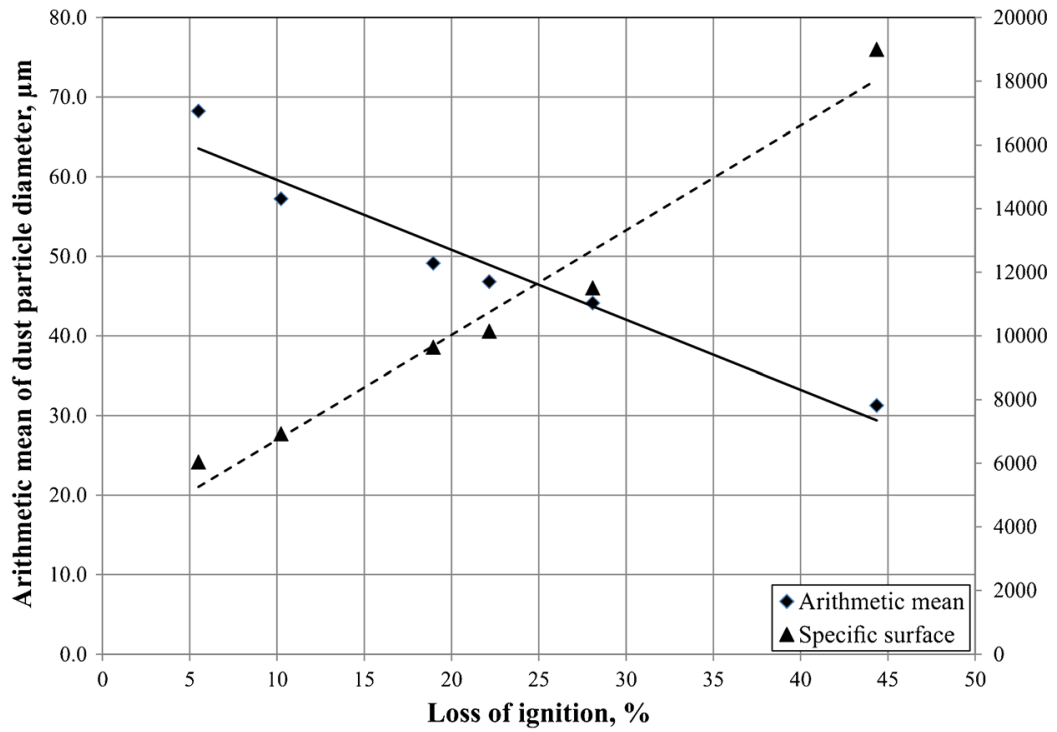

है 
Fig. 6 Mass fraction of dust particles sized $1.0-56.0 \mu \mathrm{m}$ vs. their loss on ignition

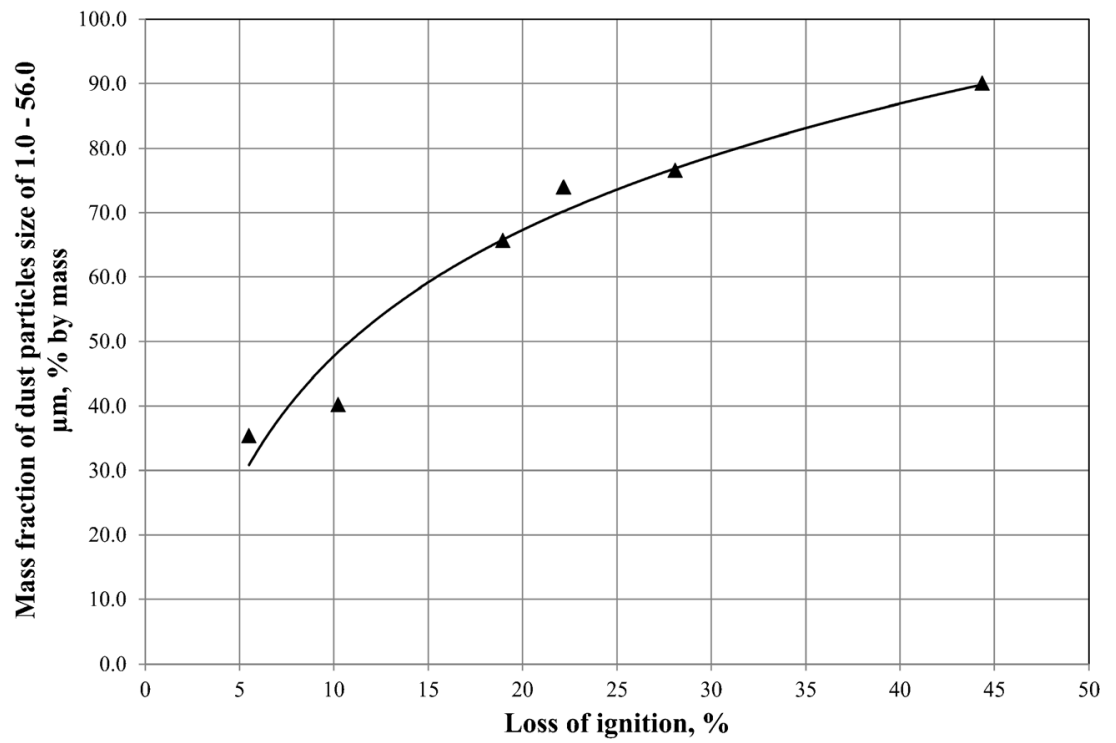

Table 3 presents selected data of the size analysis of dusts from the moulding sands with furfuryl resins and with alkaline resins conducted by the laser diffraction method by means of the Analysette 22 Nano Tec apparatus (Dańko and Holtzer 2010).

The main fraction of all dusts comprised grains of sizes 1$56 \mu \mathrm{m}$. The mass fraction of dust particles sized 1.0-56.0 $\mu \mathrm{m}$ varied from 40.24 to $90.03 \%$ by mass for all tested dusts (Fig. 5). The typical median diameter of after reclamation dusts should be up to $70 \mu \mathrm{m}$, and this value informs about the effectiveness of operation of sand dedusting system in the foundry. Dusts D4, D6 and D7 had the highest homogeneity with respect to grain composition. These dusts also had the largest specific surface. As can be noticed on the basis of Fig. 6, the arithmetic mean of the dust decreased approximately linearly with the increasing value of its LOI; specific surfaces of the investigated dusts behaved conversely. Other major components of after-reclamation dusts were $\mathrm{Al}_{2} \mathrm{O}_{3}$, up to $10 \%$, and $\mathrm{Fe}_{2} \mathrm{O}_{3}$, up to $7 \%$.

Since one of the directions of the management of afterreclamation dusts originating from moulding sands with organic binders is their thermal utilisation, e.g., in the process of co-burning with carbon carriers or in individual burning, it is necessary to determine the energy properties of these dusts.

The results of the technical analysis and the energy properties data of after-reclamation dusts are presented in Table 4 .

After-reclamation dusts originating from the mechanical reclamation processes of moulding sands with various resins significantly differ in their physicochemical properties, chemical compositions and energy properties. This is mainly caused by the applied reclamation system and its efficiency, by the efficiency of the reclaimed material dedusting system
Table 4 Energy properties data and technical analysis of dusts from the mechanical reclamation process of moulding sands with furfuryl resins and with alkaline resins

\begin{tabular}{lllllll}
\hline Determined property, symbol (metric unit) & \multicolumn{7}{l}{ Marking of after-reclamation dust } \\
\cline { 2 - 8 } & D1 & D2 & D4 & D6 & D3 & D7 \\
\hline Residue of combustion content, $A^{a}$ (\% by mass) & 80.3 & 87.9 & 55.2 & 71.3 & 93.9 & 77.4 \\
Volatile matter content, $V^{a}(\%$ by mass) & 6.92 & 3.96 & 12.50 & 9.94 & 3.70 & 7.82 \\
Heat of combustion, $Q_{s}^{a}(\mathrm{~J} / \mathrm{g})$ & 5004 & 2806 & 13,746 & 7108 & 1382 & 6770 \\
Calorific value, $Q_{i}^{a}(\mathrm{~J} / \mathrm{g})$ & 4838 & 2717 & 13,439 & 6884 & 1304 & 6590 \\
Total sulphur content, $S_{t}^{a}(\%$ by mass $)$ & 0.81 & 0.50 & 1.94 & 1.13 & 0.04 & 0.02 \\
Sulphur content in the residue of combustion, $S_{A}^{a}(\%$ by & 0.16 & 0.02 & 0.35 & 0.06 & 0.04 & 0.02 \\
$\quad$ mass) & 0.65 & 0.48 & 1.59 & 1.07 & - & - \\
Combustible sulphur content, $S_{C}^{a}(\%$ by mass $)$ & 14.7 & 8.4 & 35.3 & 20.1 & 4.0 & 18.4 \\
Content of carbon, $C_{t}^{a}(\%$ by mass $)$ & 0.65 & 0.34 & 1.16 & 0.86 & 0.29 & 0.77 \\
Content of hydrogen, $H_{t}^{a}(\%$ by mass $)$ & 0.09 & 0.43 & 0.46 & 0.80 & 0.08 & 0.77 \\
Content of nitrogen, $N^{a}(\%$ by mass) & & & & &
\end{tabular}


Fig. 7 Calorific value and residue of combustion content of the investigated dusts vs their loss on ignition

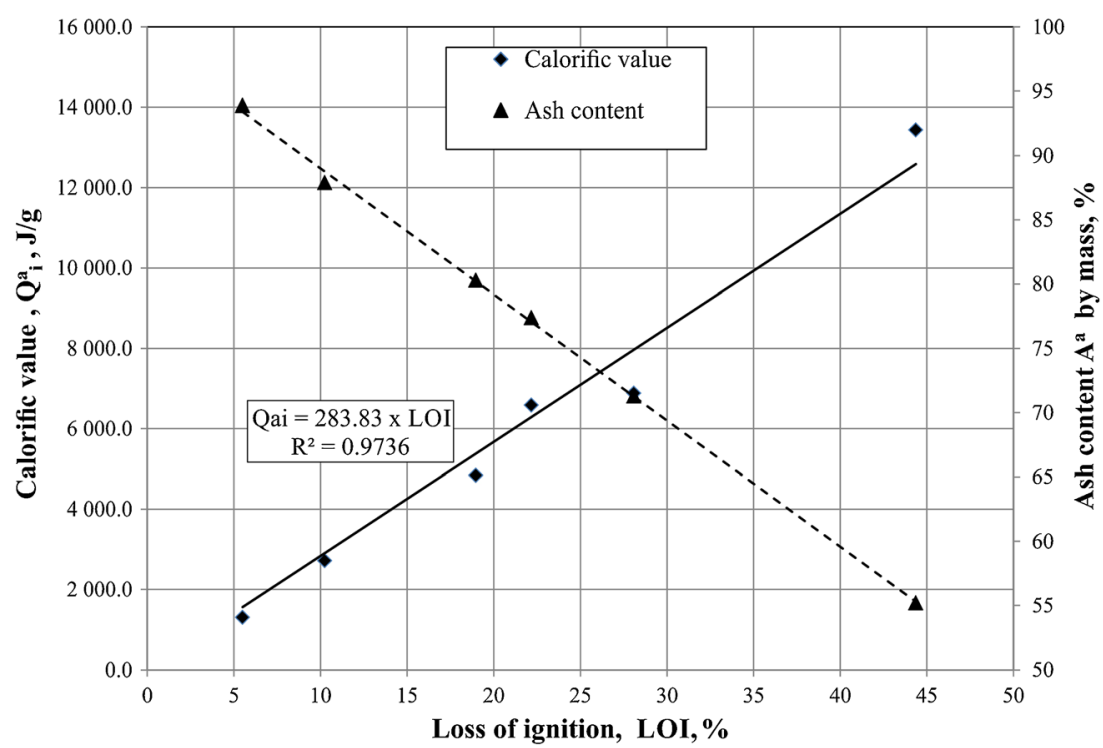

as well as by that of the mixture separation of high-silica and chromite sands applied as moulding sand matrices. From the point of view of the possibility of utilising energy stored in after-reclamation dusts in the process of their individual combustion (e.g., in gaseous furnaces) or co-burning with carbon carriers (e.g., hard coal, brown coal, etc.), the highest possible content of combustible substances (which means mainly carbon compounds) is essential.

The carbon content in the tested dusts was very different (even fourfold). The dust calorific value is strictly related to the carbon content. Dust D4 had the highest calorific value, which was more than $13 \mathrm{MJ} / \mathrm{kg}$ of dust (at a dust carbon content of app. $35 \%$ ). Dust D3 had the lowest calorific value at $1.304 \mathrm{MJ} / \mathrm{kg}$ of dust. Analysis of the data shown in Table 4 allows us to state that the amount of heat generated in the combustion process of organic components of after-reclamation dusts, as represented by the calorific value, can be related to values which are used for procedures of the dusts' quality estimation and even for estimation of the quality of the reclamation process, such as ignition loss values, carbon content or organic substances total content.

The obtained data indicate the linear dependence of loss of ignition and calorific values of dusts for the whole range of the investigated dusts (Fig. 7). The same relation can be noticed in the case of ash content. Parameterisation of the measurements allows for direct utilisation of temporarily determined ignition loss values for approximate assessment of calorific values of after-reclamation dusts.

Dusts D4 and D6, with the highest carbon content, are characterised by a significantly lower ash content which is, respectively, 55.2 and $71.3 \%$ (which means a lower content of the inorganic components, mainly $\mathrm{SiO}_{2}$, than in the remaining dusts).

\section{Conclusions}

Six different dusts were investigated originating from mechanical reclamation processes of moulding sands with furfuryl, ALPHASET and alkyd resins. The obtained results indicate the following conclusions:

- Taking into account the relatively high calorific values of some of the investigated dusts (mainly D4 and D6), it can be assumed that an efficient method of their utilisation will be either combustion in a gas stream or co-burning with solid carbon carriers.

- The large carbon content in after-reclamation dusts and simultaneously a high calorific value of such dust indicates that it contains significant amounts of organic compounds.

- Too intensive dedusting can cause excessive carrying off of silica dusts, which will generate larger amounts of dusts but will not increase the calorific values of these dusts nor will it cause better purification of matrix grains from binder coatings.

- It is necessary to develop such a system of thermal utilisation of these dusts which would allow for selfregulation of energetic fuel additions depending on the current calorific value.

- The more efficient the reclamation process is aimed at removal of the binder coatings from the grain surfaces, the larger the dust amount is. Another factor influencing 
the amounts of after-reclamation dusts can be the efficiency of the dedusting system.

Acknowledgments This research study is financed by the National Centre for Research and Development within the INNOTECH-K1/IN1/ $57 / 156360 / \mathrm{NCBR} / 12$ project conducted in the years 2012-2015 at AGH University of Science and Technology, Foundry Engineering Faculty, Krakow, Poland.

Open Access This article is distributed under the terms of the Creative Commons Attribution 4.0 International License (http:// creativecommons.org/licenses/by/4.0/), which permits unrestricted use, distribution, and reproduction in any medium, provided you give appropriate credit to the original author(s) and the source, provide a link to the Creative Commons license, and indicate if changes were made.

\section{References}

Crandell GR (2006) CERP organic HAP emission measurements for iron foundries and Their use in development of an AFS HAP guidance. AFS Transactions. http://www.afsinc.org/files/1412-317\%20afs\% 20paper\%2006-031\%20public_1383851854293 5.pdf. Accessed 20 June 2015

Dańko R (2010) Experiences gathered during reclamation of used water glass and bentonite sands in extra low and ambient temperature. Int J Cast Met Res 23:92-96. doi:10.1179/174313309X451270

Dańko R, Holtzer M (2010) Moulding sands grain size investigations by means of the laser method of measurement. Arch Metall Mater 55: 787-794

Dańko J, Dańko R, Łucarz M (2007) Processes and devices for reclamation of used moulding sands. Akapit, Kraków

Dańko R, Holtzer M, Dańko J (2014) Investigations of physicochemical properties of dusts generated in the mechanical reclamation process of spent moulding sands with alkaline resins. China Foundry 11:132-138

Dondi M, Marsigli M, Fabbri B (1997a) Recycling of industrial and urban wastes in brick production: a review (part 2). Tile Brick Int 13(4): 302-309

Dondi M, Marsigli M, Fabbri B (1997b) Recycling of industrial and urban wastes in brick production: a review (part 1). Tile Brick Int 13(3):218-225
Fontes Vieiraa CM, Sancheza R, Neves Monteirob S, Lallac N, Quarantac N (2013) Recycling of electric arc furnace dust into red ceramic. J Mater Res Technol 2:88-92

Holtzer M (2011) World development tendencies in the field of moulding and core sands with regard to their environmental impact. Przegl Odlewnictwa 3-4:112-121

Holtzer M, Dańko R, Żymankowska-Kumon S (2014) The state of art and foresight of world's casting production. Metalurgija Metallurgy 53: 697-700

Holtzer M, Dańko R, Dańko J, Pytel Z (2015) Utilisation of products of the thermal reclamation of post reclamation dusts in the production technology of ceramic building materials. Arch Foundry Eng 15(4): 33-37

Jezierski J, Janerka K (2011) Selected aspects of metallurgical and foundry furnace dust utilization. Pol J Environ Stud 20:101-105

Laforest G, Duchesne J (2006) Characterization and leachability of electric arc furnace dust made from remelting of stainless steel. J Hazard Mater B135:156-164. doi:10.1016/j.jhazmat.2005.11.037

Łucarz M (2015) Setting temperature for thermal reclamation of used moulding sands on the basis of thermal analysis. Metalurgija Metallurgy 54:319-322

Łucarz M, Grabowska B, Grabowski G (2014) Determination of parameters of the moulding sand reclamation process, on the thermal analysis bases. Arch Metall Mater 59:1023-1027

Pribulova A, Gengel P (2010) Odpady z vyroby ocelovych odliatkov. Kosice

Reardon EJ, Czank CA, Warren CJ, Dayal R, Johnston HM (1995) Determining controls on element concentrations in fly ash leachate. Waste Manag Res 13:435-450

Skrzyński M, Dańko R, Kamińska J (2013) Reclamation of mixtures of spent sands of inorganic and organic type. Arch Foundry Eng 13(4): 93-96

Stegemann JA, Roy A, Caldwell RJ, Schilling PJ, Tittsworth R (2000) Understanding environmental leachability of electric arc furnace dust. J Environ Eng 126:112-120

Vargas AS, Masuero AB, Vilela ACF (2006) Investigations on the use of electric-arc furnace dust (EAFD) in Pozzolan-modified Portland cement I (MP) pastes. Cem Concr Res 36(10):18331841

Vieira CMF, Monteiro SN (2009) Incorporation of solid wastes in red ceramics — an updated review. Rev Mater 14(3):881-905 